\title{
Gun Violence in the United States: A Public Health Epidemic
}

\author{
Amy J. Thompson \\ The University of Toledo \\ USA
}

\section{Introduction}

Guns in America are not distributed evenly and once a firearm is purchased it is often retained by the owner for a substantial time due to its long-lasting design. It is estimated that about 34 million individuals own 195 million guns (Bureau of Alcohol, Tobacco, and Firearms, 2000). Estimates of private gun ownership are difficult to determine as there are few states that require firearm registration. There are two proxy methods that are commonly utilized to determine such estimates. Sales for the most widely sold gun magazine, Guns and Ammo, has been used to estimate gun ownership as well as the fraction of suicides in which a gun was involved (Duggan, 2001). Gun ownership seemed to peak in the early 1970's and since 1973 has declined. This decline would contradict the popular notion that gun ownership is escalating and that increased gun ownership is necessary to counteract the possibility of home invasion. While gun ownership has declined, handgun ownership has increased compared to shotguns and rifles (Blendon et al., 1996). Currently, an estimated 35\% of households have at least one gun (Bureau of Alcohol, Tobacco, and Guns, 2000). Approximately, one in about four households contains a handgun (Smith, 2001).

According to a study by Cook \& Ludwig (1997), the typical gun owner possesses multiple guns, is male, and is Caucasian. Gun ownership is highest among middle-aged, collegeeducated people in rural or small towns. A strong predictive factor of gun ownership is the presence of guns in an individual's home during childhood. Self-defense and recreation are the single most common reasons for purchasing a gun (Cook \& Ludwig, 1997). A substantial minority of Americans (22\%) report that they rarely leave home without a gun. On an average day, it is estimated that 1.1 million people carry a gun on their person outside of the workplace, while another 2.1 million store a firearm in their vehicle (Cook \& Ludwig, 1997). According to Youth Risk Behavioral Surveillance System conducted by the Centers for Disease Control and Prevention (CDC) in 2009, six percent of high school students have carried a gun in the last 30 days.

The majority of guns purchased were obtained by their owners through federal firearm licensed dealers (FFL). However, a substantial number of guns (30\% to $40 \%)$ are purchased through secondary sources that include gun shows, pawnbrokers, and newspaper classifieds (Cook, Molliconi \& Cole, 1995). Under federal law, any gun purchased through a FFL requires a criminal background check. In most states, secondary sales do not require that the purchaser undergo a criminal background check. Secondary sales account for the 
majority of guns identified in crime traces (Cook, Braga, 2001). Another noteworthy source of gun acquisition is through theft. Each year more than 171,000 guns are stolen (Americana for Gun Safety, 2001)

The United States is not especially more violent than many other industrialized countries, yet the rate of firearm death is nine times greater than all other industrialized countries combined. In fact, the United States firearm death rate is three times higher than France, nearly five times higher than Israel, 12 times higher than Germany, 33 times higher than Great Britain, and 285 times greater than Japan (Krug, Powell \& Dahlberg, 1998). Research suggests that it is ready access to guns that has drastically elevated the incidence and prevalence of firearm death and injury in the United States compared to other nations. The availability of guns has increased rates of violent crime across the United States. A study by Price, Thompson \& Dake (2004) examined state variations in homicide suicide, and unintentional injury. They found in states with higher gun ownership there were also higher rates of firearm homicide, suicide, and unintentional injury. In other words, where there were more guns, there were more gun deaths. In a study by Webster, Gainer \& Champion (1993), individuals who were more likely to carry guns were also more likely to be arrested, victims of violence, initiators of fights, and were willing to justify shooting someone.

Many people keep guns in readily available locations in their homes for personal protection. Research on police records involving home invasion data indicates that even in homes with guns, seldom are residents able to use a gun for self-defense. Despite this fact, many homeowners still perceive that owning a gunwill make the home safer. Howard, Webster, \& Vernick (1999) conducted telephone interviews with a random sample of 4,138 individuals in urban areas. Twenty-nine percent of respondents believed that keeping a gun in the home would make them safer, $40 \%$ said less safe, $23 \%$ said that it depends, and $9 \%$ were unsure. It is quite possible, that the perceived benefits of having a gun for home protection are outweighed by the risks (Kellerman \& Reay, 1986). Contrary to the idea that an individual will be more likely to use a gun to protect himself/herself or family members from an intruder a study by Kellerman \& Reay (1986) indicated that for every case during a six year period in King County, Washington in which an individual used a firearm for a self-defense homicide there were 1.3 unintentional deaths, 4.6 criminal homicides, and 37 suicides involving guns. Other surveys have estimated that defensive gun use in the U.S. ranges from 61,000 to 23 million each year (Rand, 1994; Kleck \& Gertz, 1995; Cook \& Ludwig, 1997). Studies such as Kleck \& Gertz's (1995) have estimated defensive gun use within the home at 800,000 per year but this figure has been criticized due to poor methodology (Hemenway, 1997). Data from California collected from 1990 through 1995 found that $17 \%$ of people murdered in a home were killed by a stranger. Of those killed in their homes, two-thirds knew their killer. When the shooting occurred in the shooters home, 63\% of those killed were intimates or family members and $29 \%$ were acquaintances (California Department of Health Services, 1998). Thus, it would seem that the vast majority of firearm shootings occur among acquaintances rather than strangers.

\subsection{Health and economic impact of guns}

Each day in America more than 80 Americans die from firearm related injuries (CDC Wisqars, 2011).). Overall, guns are the second leading cause of fatal injury for Americans of all ages, second only to automobile accidents (CDC Wisqars, 2011). Suicide accounts for the 
majority (58\%) of firearm fatalities, followed by homicide $(39 \%)$ and unintentional injury (2\%) (CDC Wisqars , 2011).

Males account for the vast majority $(86 \%)$ of persons who die from gun trauma (CDC Wisqars , 2011). In African Americans, guns are the leading cause of death among the 15-24 age group (CDC Wisqars, 2011). In addition to the enormous human toll guns place on our society's health, the cost of treating these injuries impose a significant economic burden on our nations' taxpayers. In a study by Cook, Lawerence, Ludwig \& Miller (1999) it was determined that the mean medical cost to treat a gunshot wound was about $\$ 17,000$. Collectively in 2005, gunshot injuries in the United States cost $\$ 106,270,000$ in medical expenditures. If you combine medical costs, with lost work time the overall expenditure is $\$ 27,673,032,000$. Taxpayers end up paying high costs for medical care for victims of gunshot wounds due to the fact that this type of injury disproportionately impact those without private healthcare insurance. A study of gun-related hospitalizations in California revealed that $56 \%$ of patients hospitalized for firearm wounds relied on public health insurance, while 19\% were totally uninsured (Vassar, Kizer, 1996). The most recent national data available suggests that the percentage of people who are injured by gun trauma who are uninsured has risen to $29 \%$ (Coben \& Steiner, 2003).

\subsection{Gun homicides}

In the United States there were 12,179 homicides from guns in 2008 (CDC, 20011). Guns are often the weapon of choice by those committing a homicide. According to the Center for Disease Control and Prevention, 38 percent of firearm deaths are homicides (Figure 1). Homicide disproportionately affects young African American males. In fact, homicide is the leading cause of death for African American male youths. The gun homicide rate for African American men ages 18-29 is 133 per 100,000. This rate is about 25 times the rate for white males in that age group (Cook \& Ludwig 2000). Gun homicide also disproportionately occurs in predominantly urban areas. If a gun homicide does occur in a rural area, it is more likely to involve a white male (Cook et al., 2001).

Although guns are more likely to result in completed suicides than homicides, it is criminal homicides that often cause the greatest public concern. Although many individuals purchase a gun for personal protection against possible homicide or crime there is a significant relationship between those who purchase a firearm and the risk of their own homicide (Cummings, Koepsell, Grossman, Savarino,\& Thompson, 1997). Cummings and colleagues, (1997) found that homicide victims, when compared to controls, were more likely to have either purchased a handgun or have a family history of a handgun purchase. The connection between the family history of a handgun purchase and homicide is not surprising considering that the majority of homicides occur either between two people who are family members or who are acquaintances (Bureau of Justice Statistics, 2001). Thus, contrary to popular notion, the person who is most likely to kill you is someone you know as compared to a stranger. Weapon selection is often linked to the likelihood of a homicide occurring. In many attacks, the assailant often lacks a clear or sustained mind or intent to kill (Cook et al., 2001). Whether the victim lives or dies often depends on the lethality of the weapon chosen. Unfortunately, for many victims, guns are the weapon of choice by their attacker. Compared to many other possible weapons, a gun can be fired from a significant distance and often does not give the victim the opportunity to overcome the assailant. Guns can also inflict more injury with relative ease when compared to other weapons (Cook et al., 2001) 


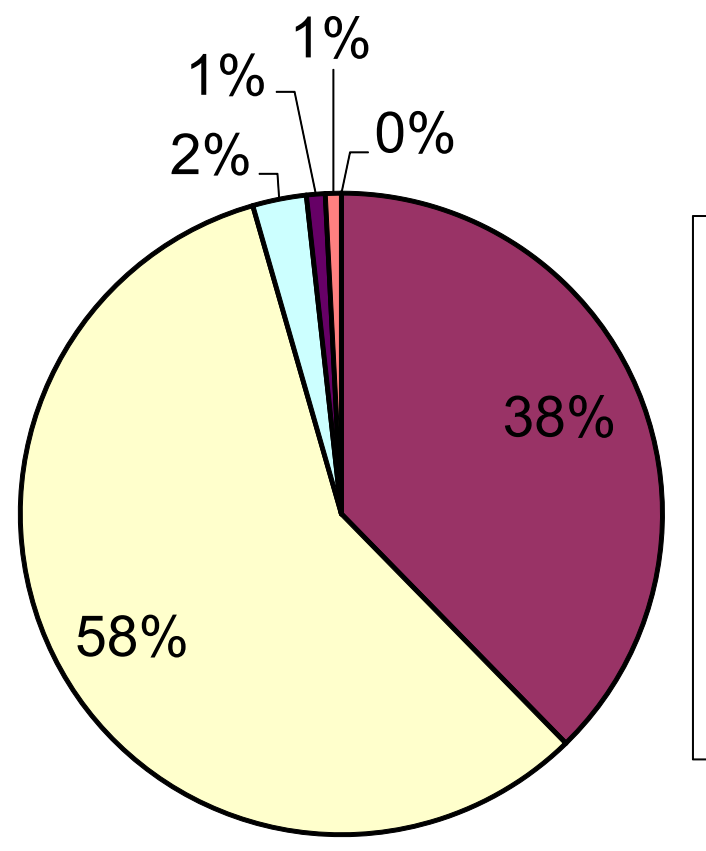

\section{口Homicide}

$\square$ Suicide

\section{口Unintentional}

\section{$\square$ Legal Intervention}

\section{$\square$ Undetermined Intent}

Data Source: CDC, 2011

Fig. 1. 2008 Gun Death by Intent in the United States

\section{Firearm suicides}

Fir suicides have dramatically increased since the 1950's. According to the Centers for Disease Control and Prevention, (2011) in the United States, more people kill themselves with guns than with all other methods combined (Figure 2). In 2008, there were approximately 36,035 suicide deaths among Americans and $50 \%$ of these deaths were caused by guns (CDC Wisqars, 2011) . Community suicide rates are greatly influenced by gun availability (Markush \& Bartolucci, 1984; Miller \& Hemenway, 1999). Brent and colleagues (1994) provided data to suggest that access to guns is a critically important risk factor for adolescent suicide. In their analysis, they found that guns were twice as likely to be found in the home of suicide victims than in the home of suicide attempters. In other words, those who actually completed suicide were more likely to use a gun. Both suicide rates and unintentional gun injuries are increasing due to availability and access to guns (Miller, Azrael \& Hemenway, 2001). Contrary to popular belief, more people die from gun suicide than from gun homicide. In 2011, there were 1.5 times as many suicides as homicides (CDC Wisqars , 2011).

Guns account for more completed suicides than any other means for men, women, and children. This should not be surprising considering due to the lethality of guns compared to other methods. Expert opinion and related evidence support the idea that both intent and instrumentality matter, individuals who commit suicide often do so when confronting a severe but temporary crisis (Seiden, 1977). For example, a study conducted by Chapdelaine, Samson \& Kimberly (1991) found that $92 \%$ of gun suicide attempts resulted in death compared to $78 \%$ 
of attempts using carbon dioxide or hanging, $67 \%$ using drowning, and $23 \%$ of intentional drug overdoses. A further study by the Centers for Disease Control and Prevention (1997) found that for every uncompleted gun suicide there were five completed gun suicides.

Impulsiveness appears to play an important role in suicide, especially among youth suicides. It is not uncommon for adolescents to have passing suicidal impulses and the availability of a gun increases the likelihood suicide will be completed. Research has determined that in many cases of suicide attempts if the individual survives the initial attempt then he/she did not have a true sustained desire to die (Blumentahl \& Kupter, 1990).

Access to a firearm in these situations may prematurely end someone's life who never intended to die. For example, in one study of 18 men who survived self-inflicted intentional gunshot wounds to the face, subsequent suicide attempts were uncommon (Miller, 2001). Another study by Chapdelaine and colleagues (1991) examined self-inflicted gunshot wounds and the impulsiveness that may occur in those contemplating suicide. Out of the 30 suicide attempters observed, none had written a suicide note, and more had reported suicidal thought for less than 24 hours. Subsequent follow up of these individuals revealed that after two years, none of the 30 people attempted suicide again.

Kellerman and colleagues, (1992) found that people living in a household with a gun are almost five times more likely to die by suicide than people who live in gun-free homes. Miller (2001) also confirmed the risk of household gun ownership and suicide using state level data from 1988-1998. In this particular study, there was a strong statistical relationship found between household gun ownership and suicide. This relationship could be seen in both genders and for every age group. These findings again suggest that having a firearm available for ready access may increase the chances of injury whether it be through homicide or suicide.

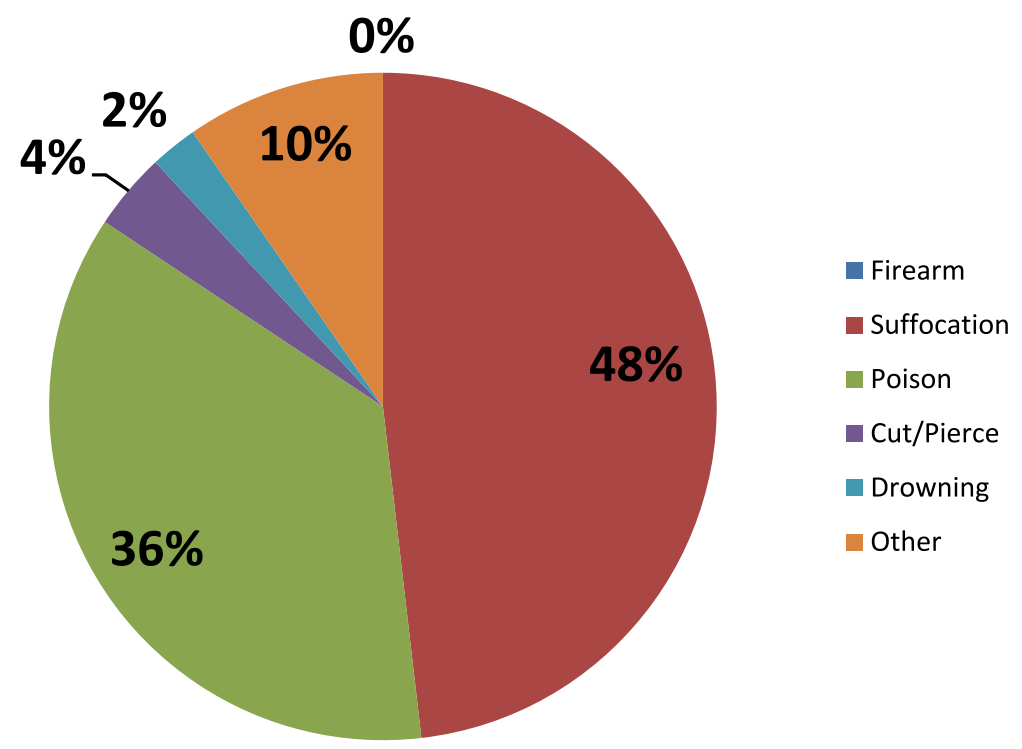

Data Source: CDC, 2011

Fig. 2. Method of Suicide in the United States 2008 
While access to guns may contribute to suicide completion one of the largest groups impacted by firearm suicide is adolescents. In 2008, 748 young people ages 19 and younger used a gun to commit suicide (CDC Wisquar, 2011). Forty percent of young people who commit suicide use a gun (CDC Wisquar, 2011). As previously discussed, impulsiveness may play a key role in suicide death but this may be particularly true for adolescents who may contemplate suicide. In a study by Shah, Hoffman, Wake and Marine (2000) of 36 adolescents who committed suicide, $67 \%$ did so with a gun obtained from their own home. Therefore, a recommendation to decrease the risk of suicide for adults and adolescents would be to limit household access to guns (Shah et al., 2000).

\section{Unintentional gun injury}

In the year 2008, there were 592 unintentional gun deaths in the United States (CDC Wisqars, 2011). White males between the ages of 15-19 years account for the majority of all unintentional firearm deaths. The majority of urban unintentional firearm injuries occur with a handgun while a large proportion of rural injuries are inflicted with long-guns (General Accounting Office, 1991; Sadowski \& Munoz, 1996). Overall, unintentional gun deaths account for a relatively small portion of all gun deaths (approximately $2 \%$ ). However unintentional firearm injuries impact a substantial number of young Americans (National Center for Injury Prevention and Control, 2002). While difficult to ascertain due to lack of adequate data collection, nonfatal firearm injury is significantly higher than individual unintentional gun death, homicide, and suicide rates. For example, in 2009 there were an estimated 18,610 people in the United States treated in hospital emergency rooms for nonfatal, unintentionally inflicted gunshot wounds (CDC Wisquars, 2011).

The rate of unintentional gun deaths has declined steadily throughout the $20^{\text {th }}$ century (Ikeda, Gorwitz, James et al., 1997). This decline may be significantly impacted through the implementation of gun safety features and safe storage practices (Frattarolli, Webster \& Teret, 2002). Safe storage of guns in particular may be beneficial in the prevention of child unintentional gun injuries (Teret \& Baker, 1995). Many children are killed by guns when handling guns in the home. Knight-Bohnoff \& Harris (1998) surveyed 80 parents of children in a daycare setting. They found that $48 \%$ of parents kept at least one gun in the home. Twenty-six percent of those gun owners reported that the gun was loaded at all times, and $18 \%$ reported that a gun was kept within the reach of a child. In another study by Nelson, Grant-Worley, Powell et al., (1996), 10\% of adults who lived in households with guns stated that it was always or sometimes stored loaded and unlocked. This access accounts for the significant number of unintentional gun injuries among youth despite the steady declines. Some may argue that the reduction in unintentional gun injuries and deaths over the last century may have been a result of gun safety education that taught children not to touch a gun and how to be safe around guns. Yet, one study by Hardy, Armstrong, Martin \& Strawn (1996) found that a gun safety education program did not reduce youth's tendencies and curiosities to touch a gun when they were not supervised.

\section{Safety mechanisms to reduce unintentional firearm injury}

There are a number of technologies that exist for making guns safer yet these mechanisms are not commonly implemented by gun manufactures or purchased by consumers. Several of these options are designed to limit access to "high-risk" users such as children, youths, 
and home burglars (Frattaroli et al., 2002). One type of device designed to reduce unintentional injuries is the chamber indicator. In many handguns the handle or the grip of the gun containing the ammunition is in either a magazine or clip. In order to fire the weapon the shooter must move the slide of the firearm to bring the cartridge into firing position. During this process it is not obvious whether there is a cartridge already in the chamber because the chamber is not viewable by the user. This danger can be easily corrected by equipping all pistols and revolvers with a device that indicates whether ammunition is in the chamber (Frattaroli et al., 2002). Currently, few guns are available with such a device (Vernick, Meisel, Teret et al, 1999).

Another useful safety device is a magazine safety or disconnect. When an ammunition magazine is removed from the gun a live bullet can still remain in the chamber. Even though the magazine is not connected to the gun the weapon can still be fired with the remaining bullet. A magazine disconnect disables the gun from firing when the magazine is removed from the gun. Although patents for this device have been established for nearly a century few handguns are equipped with this technology (Frattaroli et al., 2002; Vernick et al., 1999).

Of the various techniques available to modify a gun, personalization of guns has the greatest potential to reduce the largest number of firearm deaths. Personalized guns can only be fired by the designated operator. There are a number of ways that a gun can be "personalized". These methods may include manufacturing guns with a built in combination lock or a removable trigger lock, requiring a personal identification number, or even requiring the owners fingerprints to fire the weapon (Frattaroli et al., 2002;Vernick et al., 1999). Thus, children who found a gun in their home would be unable to fire the weapon causing unintentional injury, adolescents would be prevented from accessing it to commit suicide, and criminals would be unable to use a stolen gun to commit a crime such as a homicide. Each year many unintentional gun injuries result from handling loaded guns. These safety devices have the potential to reduce a significant number of injuries, yet for the most part are not being implemented by guns manufacturers.

\section{Gun control policy debate}

Gun control is a term that encompasses many dimensions and issues. One of the most significant debates involving gun control is how some restrictions involving private ownership may violate the Second Amendment of the Constitution (Blendon et al., 1996). Other areas of debate regarding guns include: gun sales to those deemed dangerous, gun registry, and banning of specific types of guns such as machine guns, assault weapons, handguns, and manufacturing of cheaply made guns coined "Saturday Night Specials" that are easily concealed and disposed of (Blendon, et al., 1996).

Citizens differ widely in their positions on such debates. Much of the public favors gun control measures that do not impose major restrictions on gun owners. The public significantly opposes gun sales to convicted felons or individuals under the age of 18 years of age. A vast majority of individuals also support the Brady Act a law that imposes background checks and a five-day waiting period. Finally, there is also significant public support for registration of handguns and limiting gun purchases to 1 per month (Blendon et al., 1996). 
In a study by Teret and colleagues (1998), 2400 adults were surveyed concerning their views towards firearm regulation. They found that a majority of respondents favored safety standards for new handguns. These standards included childproofing (favored by $88 \%$ ), personalization (devices that permit firing only by an authorized person; $71 \%$ ), magazine safeties $(82 \%)$, and load-chamber indicators (73\%). There was also a strong public support for policies prohibiting convicted felons from obtaining guns (85-95\%) (Teret at al., 1998). There was also significant support for policies designed to reduce the illegal sale of guns, including tamper resistant serial numbers $(90 \%)$, limit of hand gun sales to one per month $(81 \%)$, and mandatory registration of handguns (82\%) (Teret et al., 1998). This study is significant because it showed strong public support, even among gun owners, for new strategies to regulate guns and make them safer. With such overwhelming public support it seems questionable why stricter firearm control policies are not being enacted at the federal and state level.

With so many types of ammunition and guns available it is difficult to establish gun laws that encompass all of these products. Consumer trends in gun purchasing are more clustered around handguns than ever. This type of weapon is used much more often in homicides, particularly fatal ones (Johnson, Coyne-Beasley \& Runyan, 2004). Handguns are both very powerful and easy to conceal. Gun manufacturers know there is a demand in this area. They are producing smaller more easily concealed handguns. In addition to this deadly design, semiautomatic handguns are being produced to rapidly reload and fire. Other products deemed "point and shoot accessories" such as laser sightings have been developed to ensure that both the target is not missed and that a clear recognition of a target is not necessary for accuracy (Wintemute, 1996).

\subsection{State and federal gun laws}

It is estimated that there are at least 300 state and federal firearm laws (Vernick, Hepburn, 2002). There have been a number of categories of gun policies that have been proposed in the literature. Some researchers suggest that restrictions should focus on the manufacture, sale, and possession of guns (Baker, Teret \& Dietz, 1980). Zimring \& Hawkins (1987) proposed gun policies that focused on restricting guns in certain places; severity of penalties, licensing, registration, and ban considerations. Kellerman (1991) has suggested applying a public health approach to firearm injury prevention. Christoffel (1991) has proposed a number of safety polices such as child access laws for preventing gun injuries in children. There are a number of firearm control policies that have been adopted at the federal and state level. Figure 3 adapted from Teret \& Wintemute (1993) provides a list of possible categories and sub categories of firearm policies .

One of the first federal laws enacted to impact the sale of guns was the National Guns Act of 1934. This law was enacted during the prohibition era and was inspired by the attempted assassination of President-elect Franklin Roosevelt (Brady Campaign, 2002). It placed a tax on manufacturers, and restricted the sale of sawed off rifles, shotguns, machineguns, and silencers. In 1938 the Federal Guns Act was passed which required annual licenses for manufacturers, dealers and importers of guns and ammunitions. Nearly 30 years later, with the assassination of Martin Luther King Jr. and Robert Kennedy in combination with rising crime rates, the Gun Control Act of 1968 was passed. Under this law, the sale of guns by dealers were banned to certain categories of people (for example, minors, convicted felons, 
mentally ill people, drug addicts, fugitives, undocumented immigrants, and anyone who was dishonorably discharged from the military). This law also required mandatory placement of serial numbers on all guns (Brady Campaign, 2002).

\begin{tabular}{|c|c|c|c|}
\hline $\begin{array}{c}\text { Policy Related to } \\
\text { Manufacture of Guns }\end{array}$ & $\begin{array}{c}\text { Regulate the } \\
\text { Manufacture of Guns }\end{array}$ & $\begin{array}{l}\text { Policy Related to } \\
\text { Sale of Guns }\end{array}$ & $\begin{array}{l}\text { Policy Related to } \\
\text { Possession of Guns }\end{array}$ \\
\hline $\begin{array}{l}\text { - Ban the manufacture } \\
\text { of all guns } \\
\text { - Ban the manufacture } \\
\text { of certain guns } \\
\text { - Ban all handguns } \\
\text { - Ban Saturday night } \\
\text { specials } \\
\text { - Ban assault weapons } \\
\text { - Ban automatic } \\
\text { weapons } \\
\text { - Ban long guns } \\
\text { - Ban other type of } \\
\text { guns }\end{array}$ & $\begin{array}{l}\text { - Personalized guns } \\
\text { - Childproofing } \\
\text { magazine and chamber } \\
\text { indicators } \\
\text { - Other safety criteria } \\
\text { for manufacture or } \\
\text { importation } \\
\text { - Regulate the } \\
\text { quantity of guns } \\
\text { manufactured } \\
\text { - Impose strict } \\
\text { liability on } \\
\text { manufactures for gun } \\
\text { injuries } \\
\text { - Tax manufacturers } \\
\text { for firearms produced }\end{array}$ & 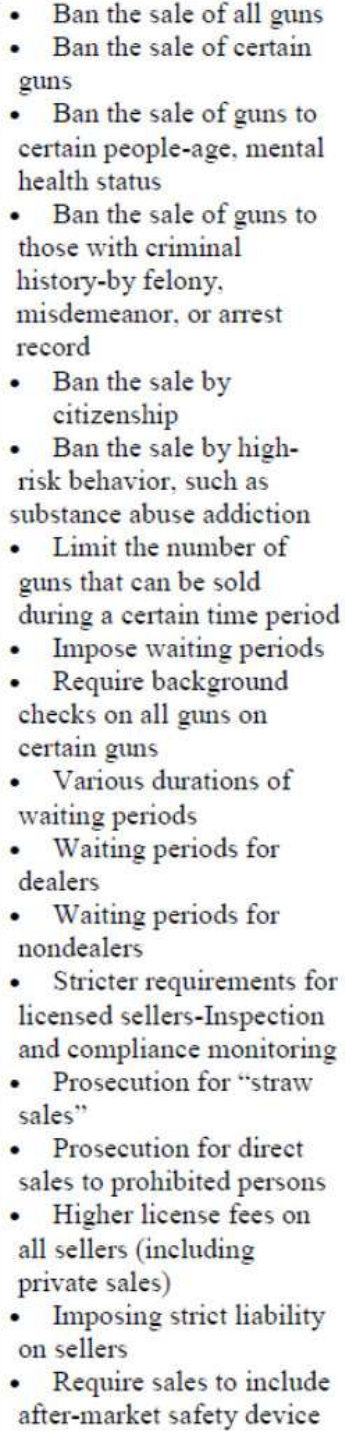 & $\begin{array}{l}\text { - Ban } \\
\text { possession of all } \\
\text { guns } \\
\text { - Ban } \\
\text { possession of } \\
\text { certain guns } \\
\text { - Ban } \\
\text { possession by } \\
\text { certain people } \\
\text { - Register } \\
\text { possession of all } \\
\text { guns } \\
\text { - Register } \\
\text { certain guns } \\
\text { - Increase } \\
\text { registration fees } \\
\text { - Restrict } \\
\text { possession by } \\
\text { location-public } \\
\text { places, high risk } \\
\text { places, in } \\
\text { schools } \\
\text { - Requiring } \\
\text { proper storage- } \\
\text { childproof } \\
\text { - Requiring } \\
\text { safety courses to } \\
\text { possess } \\
\text { - Licensing } \\
\text { carrying of } \\
\text { guns, type, } \\
\text { location } \\
\text { by carrying } \\
\text { mode } \\
\text { (concealed, } \\
\text { exposed) } \\
\text { - Enhance } \\
\text { detection of } \\
\text { illegal } \\
\text { possession }\end{array}$ \\
\hline
\end{tabular}

Fig. 3. Possible Gun Polices 
Twenty-five years later, a presidential assassination attempt sparked the enactment of a federal gun control law. In 1981, President Ronald Reagan was shot by John Hinckley Jr. During the assassination attempt Press Secretary James Brady was severely wounded. In 1993, the Brady Law was enacted named in honor of James Brady. Prior to the enactment of this law many states did not require a criminal background check of those who desired to purchase a firearm. The Brady Law changed this by requiring all federally licensed firearm dealers (FFL's) to complete a background check with law enforcement prior to selling a firearm. People who have guns through secondary gun sales however, are not required to undergo criminal background checks. Under this law, guns are also prohibited from being sold to those who are illegal aliens, fugitives, those adjudicated as mentally defective, those who have been issued a restraining order, and those convicted of a domestic abuse misdemeanor. Handgun sales are also not permitted to those under the age of 21 and long guns cannot be purchased by those under the age of 18 (Brady Campaign, 2002).

In addition to federal law, each state can enact its own gun laws. However, many states have preemption laws which do not permit the adoption of local ordinances. The states that do not have preemption include Alaska, California, Colorado, Florida, Hawaii, Illinois, Kansas, Maryland, Massachusetts, Montana, Nebraska, New Hampshire, New York, and Ohio (Guns Law Center, 2002). The effectiveness of many of these laws can only be speculated as the majority of them have not been rigorously evaluated. In 1978, a report was issued to Congress by the Controller General regarding the effect of gun laws on violent crime. The report suggested:

"Though much has been written on the subject of controlling guns. Only a few good empirical studies evaluate the impact of gun control laws on violent crime.... Of these studies, some attempted to show that gun control reduces homicide and some attempted to quantify the effect of different types of gun control laws. Several of these studies conclude that gun control laws, through limiting firearm availability, result in decreased murder. None of the studies demonstrate a decrease in overall level of violence attributable to gun control." (Teret \& Wintemute, 1993 p.101)

Subsequently since that report was issued, the American Medical Association (AMA) Council on Scientific Affairs issued a report of its own regarding the effectiveness of guncontrol measures. This report suggested that the problem of guns is complex and is one of the more controversial issues facing the public health profession in recent years and that more information needs to be gathered on the effectiveness of firearm control measures (AMA, 1989). This may be due to the large gaps in the evaluation of gun laws, variations of laws from state to state, and degrees of enforcement. Very few laws regulate the manufacture of guns, thus policy evaluation in that area is limited (Teret, Wintemute, 1993). Most research that has been done on the effectiveness of gun laws have focused on regulating the sale and possession of guns, and sentence enhancements when crimes are committed with a gun.

\subsection{Empirical research on the effectiveness of gun policy}

At the federal level there have been few studies that have examined the effectiveness of gun policy. Ludwig \& Cook (2000) assessed homicide and suicide rates associated with implementation of the Brady Handgun Violence Prevention Act. The Brady Handgun Violence Prevention Act was implemented in February 1994 and required those 21 years of age and older to undergo a background check and five day waiting period for those seeking 
to purchase a handgun from a federally licensed dealer. When this law went into effect, 32 states were required to conduct background checks and to undergo the five-day waiting period. From 1994-1997 the impact of the Brady Law was followed and it was found that changes of homicide and suicide for those states who implemented the Brady Law were not significantly different from those states that were not required to implement the law. The Brady Law did seem to have been associated with a reduction in suicides by those over the age of 55. This may be due to the waiting period requirement. Because the Brady Law was changed with the implementation of the instant background check system and was only in place for a few years it may be difficult to ascertain any potential benefits this federal law would have made had the waiting period portion of this law remained intact.

At the state level, restrictions of the sale of guns may prove to have some merit in reducing crime and injury. Webster, Vernick \& Hepburn (2001) examined the relationship between licensing, registration, and other gun sale laws in regards to the source of state crime guns. They found that states with registration and licensing systems were less likely to have guns sold within the state that were recovered in crimes. Weil \& Knox (1996) examined the effects of limiting handgun purchase though one handgun per month on the interstate transfer of guns, and the effects of licensing and registration. They also reported a decrease in state level crime. In 2002, Webster, Vernick \& Hepburn assessed the effect of the 1988 law that the Maryland legislature passed which limited the sale of certain types of small concealable handguns known as "Saturday Night Specials". This study found a delayed or gradual effect of the ban that produced estimates indicating that firearm homicide rates were 6.8$11.5 \%$ lower than would have been expected without the ban.

A number of studies have researched the outcomes of limiting the possession or access of guns. Cummings, Grossman, Rivara \& Koepsell (1997) found a relationship between child access prevention (CAP) laws that make guns less accessible to children by holding adults criminally responsible for youth access. In those states where CAP laws have been in existence for at least one year, unintentional gun deaths were reduced by $25 \%$. A follow-up study by Webster \& Starnes (2000) utilized a pooled time series model to determine validity of the study by Cummings and colleagues. Webster and colleagues (2000) found a reduction in unintentional injury death among those 15 years and younger, but the reduction was a smaller decline (17\% vs $25 \%)$ than found by Cummings and colleagues (1997).

Some states have banned the possession of certain types of guns as well as having placed restrictions on how guns can be carried. In 1976, the District of Columbia passed the Guns Control Regulations Act, which prohibited the purchase, sale, transfer, and possession of handguns by civilians unless they previously had owned a handgun and registered it. Loftin, McDowell, Wiersma \& Cottey (1991) evaluated the impact of this law and that passage of the law coincided with a decline of about $25 \%$ in the rates of homicide and suicide by gun. As a measure of validity, surrounding metropolitan areas that did not have the restrictions imposed were studied during the same period of time. There were no similar reductions in homicide and suicide by guns found and thus the authors concluded the law prevented an average of 47 deaths per year after the law was implemented. This effect persisted through 1987, which may have resulted in more than 500 lives being saved (Teret et al., 1993). Also, during the early 1970's Massachusetts adopted a law known as the Bartley-Fox Amendment. This law strengthened handgun-licensing protocol, and established a one-year mandatory prison sentence for carrying a gun that was not properly 
licensed. Under this law, all of those convicted must serve their entire sentence and were not eligible for early parole or probation. Beha (1977) evaluated the effectiveness of this law and found that a publicized threat of mandatory sentencing for carrying an unlicensed firearm was effective in deterring crime. Pierce and Bowers (1981) in a follow up study of the same law also found that the law reduced the number of gun assaults however during this same time the number of non-firearm assaults increased.

Several studies have examined the impact of concealed carry weapons laws (CCW) (Lott \& Mustard, 1997; Ludwig, 1998; McDowall, Loftin, Wiersma, 1995; Ayres \& Donohue, 2002). Currently only 1 states(Illinois) entirely prohibit the carrying of a concealed weapon. "Shall issue" laws require law enforcement agencies to issue concealed weapon permits to any applicant who meets specific criteria such as minimum age, free from criminal convictions, or having a diagnosed mental illness. "May issue" laws are more restrictive and require law enforcement agencies to issue permits to individuals who qualify under limited criteria such as individuals who transport large sums of money or who work as a private investigators.

While one of the common arguments for CCW laws is to promote public safety through individual protection with a firearm, the opposite has occurred in states that have initiated such legislation. For example, a study by the Violence Policy Center (2002), revealed in Texas (one of the few states that allows the tracking of permit holders) "law abiding" permit holders were at a rate of two and a half crimes per day since the law went into effect. From 1996 to 2000, Texas concealed handgun license holders were arrested for weapon-related offenses at a rate 81 percent higher than that of the general population of Texans ages 21 and older.

Crime and violence may be easier to track in Texas but other states have found similar results after passage of CCW laws. In a study by McDowall, Loftin \& Wiersma (1995) five cities were examined in three different states that had existing CCW laws. They found that shall-issue laws were associated with significant increases in gun homicides in three of the five cities. They also found that Florida's shall-issue law was associated with an increase in homicides for the entire state.

Unfortunately, there is currently little research on the impact of "shall-issue" laws and crime. Perhaps one of the most cited pieces of literature utilized by proponents of CCW laws is Lott and Mustard's (1997) study on "Crime, Deterrence, and Right to Carry Concealed Handguns". The authors of this study suggested that concealed weapons "shall issue" laws may be an effective method in reducing crime. Moreover, these researchers proposed that more guns equate to less crime. Lott and Mustards (1997) research however has been the focus of numerous empirical studies that questioned their findings (Black and Nagin, 1998; Webster, Vernick, Ludwick, Lester 1997, Donahue and Ayres, 2003). Lott and Mustards (1997) findings are not supported by other research because of serious flaws in the study design, which biases the results toward finding crime-reducing effects. Some of the other criticisms of their study include measurement error, failure to control for variables, and omitting potentially important variables.

A study by law professors John Donohue of Stanford and Ian Ayers of Yale (2003) also contradicts the findings of Lott and Mustard (1997). One of the key findings of this study was that jurisdictions that were analyzed had an increase in crime in the "shall issue" permit states. Robbery is committed in public more than any other crime and should be the crime 
most likely to decline if the deterrence of CCW is effective. Yet in the states that have not adopted shall-issue laws there is a much lower rate of robbery than states that allow the carrying of concealed handguns

Ayres and colleagues (2003) also hypothesize that even if no one securing a concealed carry permit ever used it to commit a crime, there are still a number of avenues that crime can increase. First, even if the adoption of a shall issue-law increased the riskiness of criminal activity, it might also increase the number of criminals who would illegally carry weapons themselves, and might also increase the speed at which a criminal decides to shoot or disable a victim (as the presence of an armed victim decreases hesitation once a criminal engagement has been launched). Therefore, the number of murders and aggravated assaults might rise if criminals responded to shall-issue laws by packing more guns, carrying higherpowered weapons, and discharging them more quickly when threatened. Second, the massive theft of guns each year means that anything that increases the number of guns in America will likely increase the flow of guns into the hands of criminals, who may in turn use them to commit crime.

Proponents of CCW contend that there is an inherent need for firearm protection in public places. The typical gun permit holder however is a middle- aged white male, which is a group at relatively low risk of violent criminal victimization with or without gun ownership. Therefore it is not clear whether substantial benefits are likely to occur by further arming this group (Donahue et al., 2003). There is the perception that carrying a concealed weapon can help one to protect oneself from an unknown offender and that one could save others as well in a dangerous situation such as a robbery or a hijacking. The reality is that by having a gun in an individual's hands who is not trained to respond to such a situation could cause more harm than good. Citizens are often not adequately trained to handle guns in stressful situations. According to the FBI, in 1999, 5 out of 41 law enforcement officers killed in the line of duty were killed by an adversary with the officer's own service weapon (FBI, 1999). If this can occur to a police officer it is perhaps even more likely to happen to a lay citizen.

Other researchers have found that concealed carry laws actually increase homicide and crime rates. Ludwig (1998) analyzed state level data on concealed carry laws and found that shall issue laws have resulted in an increase in adult homicide rates. McDowall, Loftin, and Wiersema (1995) conducted a multi-state comparison on the effects of concealed weapon laws (Florida, Mississippi, and Oregon). Across the major counties studied in the three states, gun homicides increased in the aftermath of "shall issue" laws. In contrast, during the same period, homicide without weapons remained consistent. These findings were consistent even when other potential confounding variables were controlled for such as population change, variations in national homicide rates, and the enactment of other laws within the state. It was found that after the passage of the "shall issue" laws in those states that the average number of homicides in the major urban areas within those states increased by 4.5 persons per 100,000 (McDowall et al., 1995).

Studies conducted outside of the United States may also provide information on the effects of concealed weapons laws. Villaveces, Cummings \& Espitatia et al., (2000) assessed the effect of a ban on carrying guns on homicide rates in two Colombian cities. In 1983-1993 there was a $366 \%$ increase in the homicide rate in Columbia. To combat this increase, the carrying of guns was banned on weekends after paydays, on holidays, and on election days. 
Police established checkpoints to monitor compliance. During periods when the ban on carrying concealed guns was enforced homicide rates were lower than expected with an adjusted odds ratio of 0.86 .

As previously stated, the United States has the highest gun death rates in the industrialized world. One of the countries that often is compared to the United States for gun homicide and suicide is Canada. Canada has a significantly lower number of gun deaths compared to its geographic neighbor, the United States. One speculative cause of this lowered gun death rate is the stricter gun control laws that are in effect in Canada. Le Leenaars and Lester (1993) examined the effects on homicide of Canada's Criminal Law Amendment Act of 1977, which has been in effect since 1978. This law requires acquisition certificates for all guns, restricts access to certain types of guns such as handguns, reduces the availability to certain types of individuals such as felons, sets up procedures for handling and storing guns, requires permits for sellers of guns, and increases sentences for firearm offenses. Leenaars and colleagues (1993) examined Canadian homicide data from 1969 through 1985. Whereas the homicide rate during this time period did not significantly change after the passage of Canada's Criminal Law Amendment Act, the number of homicides committed with a firearm decreased from 38 percent in 1977 to 33 percent in 1985. This reduction in firearm homicides may be encouraging but there was some evidence to suggests that because the overall homicide rate in Canada did not decline that individuals intent on murders may have switched to other means.

Australia is another country in which there has been some tracking of the effectiveness of gun policy. After a lone gunman opened fire in Port Arthur and killed 35 persons, the Australian state and federal government implemented a broad plan for gun control. Within 12 months of the massacre, certain types of guns were prohibited (semiautomatic and selfloading) and new licensing, registration, safe storage, and safety training requirements were implemented. These new policies coincided with a massive gun buy-back of those weapons that were now banned. The premise behind such a buy-back program was that by reducing the number of lethal guns that gun crime, mortality, and morbidity would be reduced. After the implementation of such a buy-back program in conjunction with the other gun polices previously listed Australia did have a reduction in the number of homicides by 10 percent (Reuter \& Mouzos, 2003). Overall, the impact of all of these combined measures did not decrease the total number of suicides but did reduce the number of suicides committed with a gun. Violent crime also appears to have been impacted by these new policies. Although data suggests that the rate of attempted murder remained stable (29 percent in 1993 and 31 percent in 2000) the rate of guns used in assaults become more rare (Reuter et al., 2003). For example, in 2000 there were 141, 24 assaults, of which 786 involved the use of a gun. This translates into barely 0.5 percent of assaults being committed with a gun.

While it appears that there has been some reduction in gun homicide and violent crime in Australia after the enactment of these policies it is worth noting that research in the United States regarding gun buyback programs has been less than promising (Rosenfield, 1996). The failure of gun buy backs programs has often been attributed to the small scale of the interventions. Reuter et al., (2003) gives the example that if a gun buy-back program had a $\$ 100,000$ budget, and for each gun turned in $\$ 50$ (a typical price) was distributed, the total number of guns collected would be 2,000. This would equate to less than one percent of the guns in a city with a population of 250,000 (Kleck, 1996). The apparent difference between 
the gun buy-back programs in Australia and the United States is both the dollar amount given for the gun turned in and the scale of the campaign. In Australia the average dollar incentive awarded per gun turned in was $\$ 359$. Since this program has been in effect nearly 4.25 million guns were turned in decreasing gun ownership by 20 percent (Reuter et al., 2003).

While there has been various studies published regarding the effectiveness of various gun laws the Task Force on Community and Preventive Service (2005) has completed one of the most comprehensive and complete examination on the effects of the major gun laws. This group specifically examined bans on specific types of restrictions on gun acquisition, waiting periods for firearm acquisition, firearm registration and licensing of gun owners, CCW laws, child access laws and zero tolerance laws in schools. After careful review of the research conducted the committee issued a comprehensive report indicating there was insufficient evidence that any of the aforementioned gun laws were indeed effective. This conclusion was based on several reasons that include: too few studies, unreliable data collection methods that do not control for confounding variables, inappropriate analysis and inconsistent results

\subsection{Alternatives to the enactment of gun policy}

While the enactment of several gun laws in the United States has been successful many gun laws are too narrow to dramatically impact public health. Koop and Lundberg (1992) suggest that both gun control and violence prevention needs to encompass many different strategies. They make three recommendations: support additional research on the causes, prevention, and cures of gun violence; increase the education of all Americans about violence, and demand legislation to reverse the upward trend of injuries and deaths. Further, they recommended that a legislative approach similar to that of injury control of motor vehicles be mandated for guns. This approach encompasses modification of host, agent and environment (Figure 4)

Teret and colleagues (1993) proposed that for optimal reduction in firearm deaths a redirection of policy away from attempting to regulate the use and possession of guns towards regulating their manufacture, sale and marketing. This may be particularly successful at the state level. They argued in doing so, successful injury control could be achieved. In addition to policy implementation there may be additional strategies that may help to reduce the number of people who are killed or injured from guns. Patient counseling by the medical community may provide alternatives when firearm policy or regulation is not feasible or in addition to adoption of gun policy.

Multisite means reduction and safe storage education may be one of the most effective ways to reduce firearm injury. When patients are counseled by members of the medical or mental health community behavioral change is often observed. Such success can be seen with patients regarding smoking cessation, seatbelt use, and diet. This often is due to patients deferring to the advice of a perceived expert such as a physician, physician assistant, nurse, psychiatrist or counselor. Several studies have examined the influence and the extent of gun counseling behaviors by professionals. A study of adults' perceptions of physicians' advice with regard to not keeping guns in the home found that $47 \%$ claimed that they would follow the advice, and an additional $37 \%$ would think over the advice of the physician. 


\begin{tabular}{|l|l|l|}
\hline $\begin{array}{l}\text { Education regarding safe } \\
\text { storage and potential } \\
\text { dangers of access to guns. }\end{array}$ & $\begin{array}{l}\text { Changes in the manufacturing } \\
\text { process to require guns to have } \\
\text { safety mechanisms and to limit the } \\
\text { "kill" capacity of guns by restricting } \\
\text { the production of large capacity } \\
\text { ammunition and assault weapons }\end{array}$ \\
\hline
\end{tabular}

\section{Host}

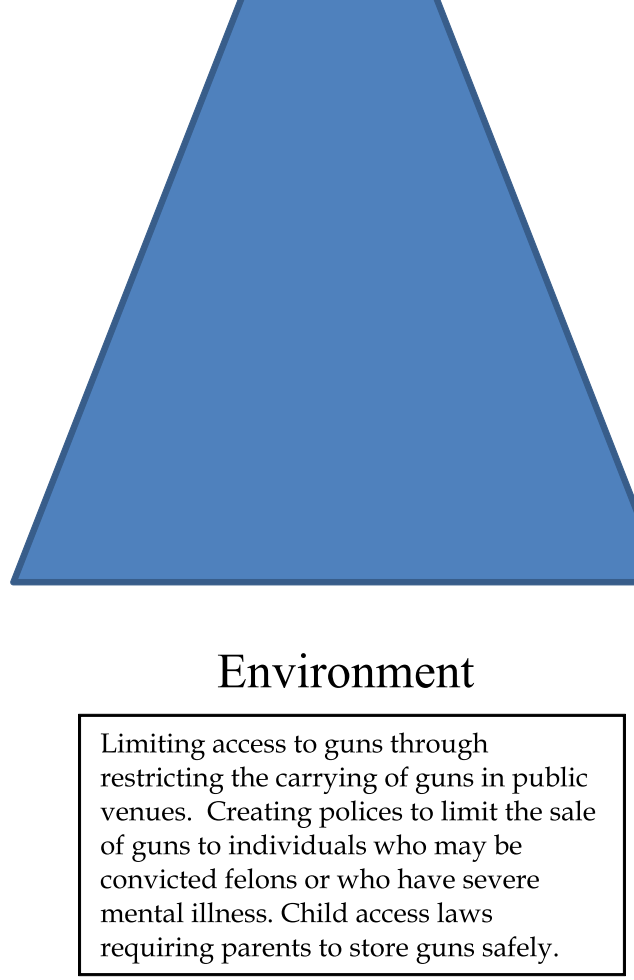

Fig. 4. Public Health Triad Model

Only 6\% claimed that they would ignore or be offended by such advice (Haught, Grossman \& Connell, 1995). In a study by Albright \& Burge (20 04) patients were randomly assigned to a control group where no gun counseling took place, verbal counseling only, or verbal counseling plus a brochure was disseminated. All education given focused on safe gun storage practices. Family physicians' brief counseling efforts made a significant positive impact in the gun storage habits of their patients. With a verbal or written recommendation, a significant improvement was observed in firearm storage. While there is evidence to suggest that counseling by healthcare and mental health providers may reduce gun access and promote safe storage many practitioners may not see this as there role and may not have received any professional training on how to discuss this issue with patients (Kinnison, Price \& Telljohann et al., 2010; Price, Thompson \& Khubchandani, nd). More training is needed for providers and additional information should be required during practicums or residency training programs (Coyne-Beasley \& Theodore, 2006). 


\section{Conclusion}

Guns have a significant impact on public health in the United States. Given the current toll of gun violence, it is clear that action is needed. While it has yet to be completely determined the extent to which all gun policies reduce gun violence and death, policies have the potential to reduce the number of firearm fatalities and injuries. While personal infringements are always a concern when enacting firearm policies there are occasions in which the "collective good" must outweigh individual perceived rights. A substantial number of the thousands of firearm homicides, suicides, and unintentional injuries should be able to be prevented without infringing too heavily on individual rights (Cook, Moore, Braga, 2001). It is only through alternative approaches such as education, policy implementation and evaluation that we can hope to develop confident conclusions about which strategies may reduce firearm violence and death. The goal of gun control programs over the next several decades should be to develop, implement, and evaluate specific gun control measures that can reduce firearm homicide, suicide, injury, and crime while preserving much of the legitimate uses of guns as possible (Cook et al., 2001). Both gun owners and nonowners express support for some gun control policies yet legislators at the state and the federal level continuously fail to enact such legislation.

\section{Acknowledgement}

The author would like to acknowledge Dr. James Price and Dr. Joseph Dake at the University of Toledo for their contribution to this work.

\section{References}

Albright, T. \& Burge, S. (2003). Improving firearm storage: Impact of a brief intervention of firearm counseling by family physicians. Journal of American Board Family Practice, $16,40-6$.

American Medical Association on Scientific Affairs. (1989). Firearm injuries and deaths: A critical health issue. Public Health Reports, March 111-120.

Annest, J., Mercy, J., Gibson, D., Ryan, G. (1995). National estimates of the nonfatal firearmrelated injuries: beyond the tip of the iceberg. Journal of the American Medical Association, 273(22),1749-1754.

Ayres, I., Donohue, J. (2003). Shooting down the more guns, less crime hypothesis. In Evaluating Gun Policy Brookings Institute Press pp.287-341.

Black, D., Nagins, D. (1998). Do right-to-carry-laws deter violent crime? Journal of Legal Studies, 27, 209-219.

Blendon, R., Young, J., Hemenway, D. (1996). The American public and the gun control debate.Journal of the American Medical Association, 275 (22), 1719-1722.

Bonnie, R., Fulco, C., Liverman, C. (1999). Reducing the burden of injury: advancing prevention \& treatment. Committee on Injury Prevention and Control, Institute of Medicine Report. National Academy Press. Washington, DC.

Boyd, J., Moscicki, E. (1986). Guns and youth suicide. American Journal of Public Health, 76, 1240-1242.

Brady Center. State firearm legislation. Accessed on September 23, 2011 at http://www.bradycenter.org. 
Brent, D., Perper, J., Moritiz, G., Baugher, M. (1994).Suicide in affectively ill adolescents: a case-control study. Journal of Affective Disorders, 3, 193-202.

Bureau of Alcohol Tobacco and Guns. The Gun Control Act of 1968. Accessed on September 24, 2011 at http://www.atf.treas.gov/pub/fire-explo_pub/gca.htm.

Bureau of Alcohol, Tobacco, and Guns, U.S. Department of Treasury. Commerce in Guns in the U.S. February 2000. Washington DC.

Bureau of Justice Statistics. (2011). FBI Crime in the U.S. Report.

Bureau of Justice Statistics. (2001). National Crime Victimization Survey, 1993-1999.

California Department of Health Services. (1998). Residential Firearm Homicides in California, Report no. 3

Centers for Disease Control and Prevention. (2011) WISQUAR database. Accessed on October 17, 2011.

Centers for Disease Control and Prevention. (2011) YRBSS database. Accessed on October 17 , 2011.

Centers for Disease Control and Prevention. (1999). Nonfatal and fatal firearm related injuries in the United States, 1993-1997. MMWR, 148 (45), 37-42.

Centers for Disease Control and Prevention/National Center for Health Statistics. (1997). Fatal Firearm Injuries in the United States 1962-1994. Accessed on October 17, 2011 at www.cdc.gov/ncipc/pub-res/firarmsu.htm.

Centers for Disease Control and Prevention. (1994) Deaths resulting from firearm and motor vehicle related injuries 1968-1994. MMWR, 43(3), 37-42.

Center to Prevent Handgun Violence. (1996). Denying handguns to prohibited purchasers: quantifying the Brady Law: executive summary. Accessed on March 23, 2003 at http://www.handguncontrol.org/gunlaw/bradylaew.htm.

Center for Responsible Politics. Gun Rights Recipients. Accessed on June 23, 2002 at http://www.opensecrets.org/industries/recipes.asp?Ind-Q13

Christoffel K. (1991). Toward reducing pediatric injuries from guns: charting a legislative and regulatory course. Pediatrics, 88(2), 294-305.

Coben, J., Steiner, C. (2003). Hospitalization for firearm-related injuries in the United States, 1997. American Journal of Preventive Medicine, 24 (1), 1-8.

Controller General of the United States, Report to Congress. Handgun control and effectiveness and costs. Washington DC. U.S. Government Printing Office, February 1978.

Cook, P., Braga, A. (2001). Comprehensive guns tracing strategies and investigative use of new data on guns markets. Arizona Law Review, 43 (2), 277-310.

Cook, P., Lawerence, B., Ludwig, J., Miller, T. (1999). The medical costs of gunshot injuries in the United States. Journal of the American Medical Association, 277 (28), 1853-1859.

Cook, P., Ludwig, J. (1997). Guns in America: National survey on private ownership and use of guns. National Institute of Justice Report.

Cook, P., Ludwig J. (1996). Guns in America: results from a comprehensive survey of gun ownership and use. Washington: Police Foundation

Cook, P., Molliconi, S., Cole, T. (1995). Regulating gun markets. Journal of Criminal Law and Criminology, 86 (1), 55-92.

Cook, P., (1991). The technology of personal violence, in Crime and Justice: Annual Review. 14, University Press 
Coyne-Beasley., T \& Theodore, A. (2006). Future physicians: The need for additional training in firearm injury prevention training. Southern Medical Journal 99 (3) 198199.

Denno, D., Grossman, D., Britt, J. (1996). Safe storage of handguns. What do police recommend? Archives of Pediatric and Adolescent Medicine, 150, 927-31.

Duggan, M. (2001). More guns, more crime. Journal of Political Economy, 109,1086-1114.

Federal Bureau of Investigation. (2000). Uniform Crime Reports for the United States:2000. Washington D.C.: U.S. Department of Justice.

Federal Bureau of Investigation. (1996) Uniform Crime Reports for the United States:1995. Washington D.C.: U.S. Department of Justice.

Fingerhut, L., and Kleinman, J. (1990). International and interstate comparisons of homicide among young males. Journal of the American Medical Association, 263,3290-3295.

Frattaroli, S., Webster, D., Teret, S. (2002). Unintentional gun injuries, firearm design, and prevention: what we know, what we need to know, and what can be done. Journal of Urban Health, 79(1), 233-239.

General Accounting Office. (1991). Trauma care: Lifesaving system threatened by unreimbursed costs and other factors. Washington, DC, General Accounting Office 1991 Report.

General Accounting Office. (1991). Accidental shootings: many deaths and injures caused by guns could be prevented. Washington, DC, General Accounting Office 1991 Report.

Hardy, M., Armstrong F., Martin ,B., Strawn, K. (1996). A firearm safety program for children: they just can't say no. Developmental and Behavioral Pediatrics, 17, 216-221.

Haught K, Grossman D, Connell F. (1995). Parents' attitudes toward firearm injury prevention counseling in urban pediatric clinics. Pediatrics, 96,649-653.

Hayes, R., LeBrun, E., Christoffel, K. (1999). Missing in action: health agencies lack critical data needed for firearm injury and prevention. Accessed on September 20, 2011 at http://www.childmmc.edu

Hoyer, D., Kochanek, K., Murphy, S. (1999). Final data for 1997. National Vital Statistics Reports 47(19). Accessed on July 27, 2003 at www.cdc.gov/nchs/releases/00news/final death97.htm

Kinnison, A., Price, J., Telljohann, S., King, K. \& Thompson, A. (2010). Clinical Psychologists Risk Management Practices and Perceptions. Journal of Community Health, 10,60-67.

Ikeda, R., Gorwitz, R., James, S., Powell, K, Mercy J. (1997). Fatal firearm injuries in the United States, 1962-1994. National Center for Injury Prevention and Control, Centers for Disease Control and Prevention.

Johnson RM, Coyne-Beasley T, Runyan CW. Firearm ownership and storage practices, U.S. households, 1992-2002. American Journal of Preventive Medicine, 2004: 27(2):173-82.

Kellerman, A., Westphal, L., Fischer, Harvard B. (1995). Weapon involvement in home invasion crimes. Journal of the American Medical Association, 273, 1759-1762.

Kellerman, A., Rivara, F. (1993). Gun ownership as a risk factor for homicide in the home. New England Journal of Medicine, 329, 467-472.

Kellerman, A., Rivera, F., Somes, G., Reay, D., Francisco, J. (1992). Suicide in the home in relation to gun ownership. New England Journal of Medicine, 327, 467-471.

Kellermen A. (1991). The epidemiological basis for the prevention of firearm injuries. Annual Review of Public Health, 12, 17-40. 
Kellerman, A., Reay D. (1986). Protection or peril? An analysis of firearm related deaths in the home. New England Journal of Medicine, 314,1557-1560.

Khubchandani, J, Wiblishauser, M., Price, J. \&Thompson, A. (2011) .Graduate Psychiatric Nurse's Training on Firearm Injury Prevention. Psychiatric Nursing 25 (4)245-252.

Kleck, G. (1996). Gun buy back programs: nothing succeeded like failure. In Under Fire. Police Executive Research Forum, Washington. pp. 29-53.

Kleck G \& Gertz, M. (1997). The illegitimacy of one sided speculation: Getting the defensive gun use estimate down. Journal of Criminal Law and Criminology, 87,1446.

Koop, C., Lundberg, G. (1992). Violence in America: a public health emergency. Journal of the American Medical Association, 267, 3075-3076.

Krug, E., Powell, K., Dahlberg, L. (1998). Firearm deaths in the United States and 35 other high-and upper-middle income countries. International Journal of Epidemiology, 27, 214-221.

Leenars, A., Lester, D. (1994). Effects of gun control on homicide in Canada, Psychological Reports, 75, 81-82.

Loftin, C., McDowall, D., Wiersma, B., Cottey, T. (1991). Effects of restrictive licensing of handguns on homicide and suicide in the District of Columbia. New England Journal of Medicine, 325, 1615-1620.

Ludwig,J., Cook, P. (2003). Evaluating Gun Policy Effects on Crime and Violence Brooking Institute Press, Washington DC.

Ludwig, J., Cook, P. (2000). Homicide and suicide rates associated with implementation of the Brady Handgun Violence Prevention Act. Journal of the American Medical Association, 284 (5), 585-591.

Ludwig, J. (1998). Concealed gun carrying laws and violent crime: evidence from state panel data. International Review of Law and Economics, 18 (3), 239-254.

Lott, J., Mustard, J. (1997). Crime, deterrence, and right-to carry concealed handguns. Journal of Legal Studies, 26, 1-68.

Max, W., and Rice, D. (1993). Shooting in the dark: estimating the cost of firearm injuries. Health Affairs, 12 (4), 171-185.

May, J., Hemenway, D., Hall, A. (2002). Do criminals go to the hospital when they are shot? Injury Prevention, 8(3), 236-8.

McDowall, D., Loftin, C, Wiersma. (1995). Easing concealed firearm laws: effects on homicide in three states. Journal of Criminal Law and Criminology, 86(1), 193-206

McGonial, M., Cole, J., Scwhab, C. (1993). Urban firearm deaths: A five-year perspective. Journal of Trauma, 35, 532-537.

Miller, M., Azrael, D., Hemenway, D. (2001). Firearm availability and unintentional firearm deaths. Accident Analysis and Prevention, 33, 477-484.

Nelson, D., Grant-Worley, J., Powell, J. (1996). Population estimates of household firearm storage practices and firearm carrying in Oregon. Journal of the American Medical Association, 275, 1744-1748.

Pierce, G., Bowers W. (1992). The Bartlett-Fox Gun Law's short-term impact on crime in Boston. Annals of the American Academy of Political and Social Science, 708,120-137.

Price, J., Thompson, A., Khubchandani, J \&Wiblishauser, M. \& Dowling, J. Perceived roles of emergency department physicians regarding anticipatory guidance on firearm safety . Unpublished manuscript. 
Price, J., Thompson, A. \& Dake, J. (2004). Factors Associated with State Variations in Homicide, Suicide, and Unintentional Firearm Deaths. Journal of Community Health,29 (4),271-283.

Reuter, P., Mouzos, J. (2003). Australia: a massive buyback of low-risk guns. In Evaluating Gun Policy Brookings Institute Press, Washington. pp.121-156.

Rosenfeld, R. (1996). Gun buy backs: crime control or community mobilization. In Under Fire. Police Executive Research Forum, Washington. pp1-28.

Seiden, R. (1977). Suicide prevention: a public health/health policy approach, Omega, 8, 276275.

Shah, S., Hoffman, R., Wake, L., Marine, W. (2000). Adolescent suicide and household access to guns in Colorado: Results of a case-control study. Journal of Adolescent Health, 26, 157-162.

Smith, T., Smith R. (1995). Changes in firearm ownership among women: 1980-1994. Journal of Criminal Law and Criminology, 86, 133-149.

Smith, T. (2001). National Gun Policy Survey of The National Opinion Research Center: Research Findings. National Opinion Research Center. University of Chicago. December 2001

Task Force on Community Preventive Services (2005). Guide to community preventive services. Guns law. Accessed on October 19, 2011 at www.thecommunityguide.org/violence/firearmlaws.html

Vassar, M., Kizer, K. (1996). Hospitalizations for firearm-related injuries: A populationbased study of 9562 patients. Journal of the American Medical Association, 275,17341739 .

Vernick, J., Webster, D. Hepburn, L. (1999). Effects of Maryland's law banning Saturday night special handguns on crime guns, Injury Prevention, 5, 259-263.

Vernick, J., Meisel, Z., Teret, S. (1999). I didn't know the gun was loaded: An examination of two safety devices that can reduce the risk of unintentional firearm injuries, Journal of Public Health Policy, 2, 427-440.

Vernick, J., Teret, S., Webster, D. (1997). Regulating firearm advertisements that promise home protection, Journal of the American Medical Association, 277(6), 1391-1397.

Villaveces, A., Cummings, P., Espitia, V., Koepsell, T., McKnight, B., Kellerman, A. (2000). Effect of a ban on carrying guns on homicide rates in 2 Columbian cities, Journal of the American Medical Association, 283(9), 1205-1209.

Webster, D., Vernick, J., Hepburn L. (2002). Effects of Maryland's law banning Saturday night special handguns on homicides. American Journal of Epidemiology, 155 (5), 406412.

Webster D, Vernick J, Hepburn L. (2001). Relationship between licensing, registration, and other gun sales and the source of crime guns, Injury Prevention, 7(3), 184-189.

Webster, D., Starnes, M. (2000). Reexamining the association between child access prevention gun laws and unintentional shooting deaths of children. Pediatrics, 106(6), 1466-1469.

Webster, D., Vernick, J., Ludwig J., and Lester, K. (1997). Flawed gun policy research could endanger public safety. American Journal of Public Health, 87, 918-921.

Webster, D., Gainer, P., Champion, H. (1993). Weapon carrying among inner-city junior high school students: defensive behavior vs. aggressive delinquency, American Journal of Public Health, 83, 1604-1608. 
Weil, D., Knox, R. (1996). Effects of limiting handgun purchases on interstate transfer of guns. Journal of the American Medical Association, 275(22), 1759-1761.

Wintemute, G. (1996). The Relationship between Firearm Design and Firearm Violence: Handguns in the 1990's. Journal of the American Medical Association, 275, 1749-1753.

Zimring, F., Hawkins, G. (1987). The Citizens Guide to Gun Control. New York: Macmilian. 


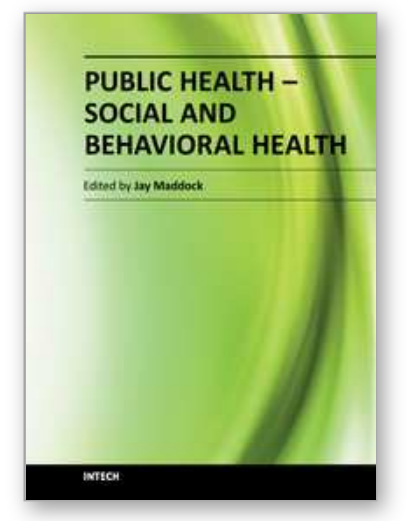

\author{
Public Health - Social and Behavioral Health \\ Edited by Prof. Jay Maddock
}

ISBN 978-953-51-0620-3

Hard cover, 570 pages

Publisher InTech

Published online 16, May, 2012

Published in print edition May, 2012

Human behavior accounts for the majority of morbidity and premature mortality throughout the world. This book explores several areas of human behavior including physical activity, nutrition and food, addictive substances, gun violence, sexual transmitted diseases and more. Several cutting edge methods are also examined including empowering nurses, community based participatory research and nature therapy. Less well known public health topics including human trafficking, tuberculosis control in prisons and public health issues in the deaf community are also covered. The authors come from around the world to describe issues that are both of local and worldwide importance to protect and preserve the health of populations. This book demonstrates the scope and some of the solutions to addressing today's most pressing public health issues.

\title{
How to reference
}

In order to correctly reference this scholarly work, feel free to copy and paste the following:

Amy J. Thompson (2012). Gun Violence in the United States: A Public Health Epidemic, Public Health - Social and Behavioral Health, Prof. Jay Maddock (Ed.), ISBN: 978-953-51-0620-3, InTech, Available from: http://www.intechopen.com/books/public-health-social-and-behavioral-health/gun-violence-in-the-unitedstates-a-public-health-epidemic

\section{INTECH}

open science | open minds

\section{InTech Europe}

University Campus STeP Ri

Slavka Krautzeka 83/A

51000 Rijeka, Croatia

Phone: +385 (51) 770447

Fax: +385 (51) 686166

www.intechopen.com

\section{InTech China}

Unit 405, Office Block, Hotel Equatorial Shanghai

No.65, Yan An Road (West), Shanghai, 200040, China

中国上海市延安西路65号上海国际贵都大饭店办公楼 405 单元

Phone: +86-21-62489820

Fax: +86-21-62489821 
(C) 2012 The Author(s). Licensee IntechOpen. This is an open access article distributed under the terms of the Creative Commons Attribution 3.0 License, which permits unrestricted use, distribution, and reproduction in any medium, provided the original work is properly cited. 